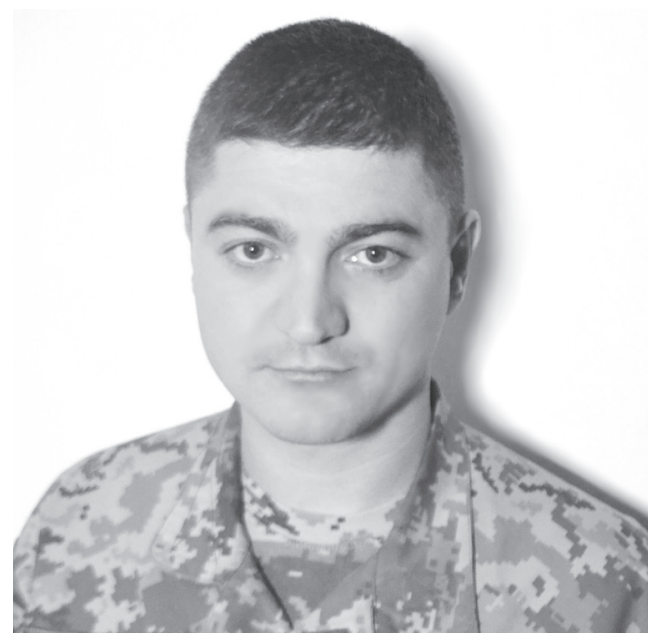

03039, м. Київ, вул. Фрометівська, 2, тел.: 06349531 43, e-mail: murashko.vitalii1981@ gmail.com

\section{Мурашко Виталий Сергеевич,}

старший преподаватель кафедры публичного администрирования, аспирант, Межрегиональная Академия управления персоналом, 03039, г. Киев, ул. Фрометовская, 2, тел.: 06349531 43, e-mail: murashko.vitalii1981@gmail.com

ORCID: 0000-0002-8668-2043

\section{UDC: 351}

DOI: https://doi.org/10.32689/2617-

2224-2019-5(20)-154-163

Murashko Vitaliy Serhiyozych,

Senior Lecturer, Department of Public Administration, Postgraduate Student, Interregional Academy of Personnel Management, 03039, Kyiv, Str. Frometivska, 2, tel.: 063495 31 43, e-mail: murashko.vitalii1981@gmail. com

ORCID: 0000-0002-8668-2043

\section{Мурашко Віталій Сергійович,}

старший викладач кафедри публічного адміністрування, аспірант, Міжрегіональна Академія управління персоналом, ORCID: 0000-0002-8668-2043

\title{
CATEGORICAL AND STATE-ADMINISTRATIVE ASPECTS OF THE NATIONAL SECURITY FORMATION
}

Abstract. The publication is devoted to the problems of categorical and stateadministrative aspects of the national security formation. The term "security" is analyzed in the process of development of ideas of the discursive democracy, where it was considered as a value, a certain public interest, a good. However, this approach does not take into account that the concept of "security" can be interpreted more broadly as a category of philosophical and, therefore, a category of theory of public policy and public administration. However, it is noted that the growing interest in studying the essence of the concept of "security", in the context of its world-philosophical understanding, depends on many factors. These include, in particular, the complexity and inconsistency of the current processes of transformation of the geo-political and geo-economic fields, the awareness of the need to solve global security problems and fundamental socio-political and socioeconomic changes that have recently been traced in many countries of the world and have a decisive impact on the international and national security. 
It is proved that the content of the national security is seen in the degree of protection of the national interests; the state of protection of the vital interests of the individual, the society and the state, environment in various spheres of life activity from internal and external threats; the state of protection of the national interests against all kinds of threats, which is achieved through the deliberate activity of the public authorities and civil society institutions in order to guarantee human rights and fundamental freedoms, their progressive development and stability of the constitutional order. At the same time, it is substantiated that the national security of the state consists not only in the protection of the national interests, but also in support of appropriate and necessary conditions of existence of both the state, society and individual citizens. Accordingly, the provision of such favourable conditions is a prerequisite for the realization of the national interests and goals.

Keywords: formation of categorical-conceptual apparatus of the national security, national security of the state, realization of the national interests and goals, defense capability of the state.

\section{КАТЕГОРІЙНІ ТА ДЕРЖАВНО-УПРАВЛІНСЬКІ АСПЕКТИ ФОРМУВАННЯ НАЦІОНАЛЬНОЇ БЕЗПЕКИ}

Анотація. Публікація присвячена проблемам категорійних та державно-управлінських аспектів формування національної безпеки. Аналізується термін “безпека” у процесі розвитку ідей дискурсивної демократії, де він розглядався як цінність, певний суспільний інтерес, благо. Однак, відзначено, що такий підхід не враховує, що поняття “безпека” можна інтерпретувати ширше, як категорію філософську, а відтак - і категорію теорії·державноï.політики та державного управління. При цьому, зазначено, що зростаючий інтерес до вивчення сутності поняття “безпека”, у контексті її світоглядно-філософського розуміння, залежить від багатьох факторів. Серед яких, зокрема, складність та неузгодженість сучасних процесів трансформації геополітичного та геоекономічного полів, усвідомлення необхідності вирішення глобальних проблем безпеки та фундаментальних суспільно-політичних та соціально-економічних змін, що останнім часом простежуються у багатьох країнах світу і мають вирішальний вплив на міжнародну та національну безпеки.

Доведено, що зміст національної безпеки бачиться у ступені захищеності національних інтересів; стані захисту життєво важливих інтересів особистості, суспільства та держави, довкілля у різних сферах життєдіяльності від внутрішніх та зовнішніх загроз; стані захисту національних інтересів від різного роду загроз, який досягається завдяки цілеспрямованій діяльності органів державної влади та інститутів громадянського суспільства з метою гарантування прав людини та основних свобод, їх прогресивного розвитку та стабільності конституційного ладу. Разом із тим, обгрунтовано, що національна безпека держави полягає не тільки у захисті національних інтересів, а й у підтримці відповідних і необхідних умов існування як держави, так і су- 
спільства та окремих громадян. Відповідно, забезпечення таких сприятливих умов є необхідною умовою реалізації національних інтересів та цілей.

Ключові слова: формування категоріально-понятійного апарату національної безпеки, національна безпека держави, реалізація національних інтересів та цілей, обороноздатність держави.

\section{КАТЕГОРИЙНЫЕ И ГОСУДАРСТВЕННО-УПРАВЛЕНЧЕСКИЕ АСПЕКТЫ ФОРМИРОВАНИЯ НАЦИОНАЛЬНОЙ БЕЗОПАСНОСТИ}

Аннотация. Публикация посвящена проблемам категорийных и государственно-управленческих аспектов формирования национальной безопасности. Анализируется термин “безопасность” в процессе развития идей дискурсивной демократии, где он рассматривался как ценность, определенный общественный интерес, благо. Однако, отмечено, что такой подход не учитывает, что понятие “безопасность” можно интерпретировать шире, как категорию философскую, а следовательно - и категорию теории государственной политики и государственного управления. При этом, отмечено, что растущий интерес к изучению сущности понятия “безопасность”, в контексте его мировоззренчески-философского понимания, зависит от многих факторов. Среди них, в частности, сложность и несогласованность современных процессов трансформации геополитического и геоэкономического полей, осознание необходимости решения глобальных проблем безопасности и фундаментальных общественно-политических и социально-экономических изменений, которые в последнее время прослеживаются во многих странах мира и имеют решающее влияние на международную и национальную безопасности.

Доказано, что содержание национальной безопасности видится в степени защищенности национальных интересов; состоянии защиты жизненно важных интересов личности, общества и государства, окружающей среды в различных сферах жизнедеятельности от внутренних и внешних угроз; состоянии защиты национальных интересов от различного рода угроз, которое достигается благодаря целенаправленной деятельности органов государственной власти и институтов гражданского общества в целях обеспечения прав человека и основных свобод, их прогрессивного развития и стабильности конституционного строя. Вместе с тем, обосновано, что национальная безопасность государства заключается не только в защите национальных интересов, но и в поддержке соответствующих и необходимых условий существования как государства, так и общества и отдельных граждан. Соответственно, обеспечение таких благоприятных условий является необходимым условием реализации национальных интересов и целей.

Ключевые слова: формирование категориально-понятийного аппарата национальной безопасности, национальная безопасность государства, реализация национальных интересов и целей, обороноспособность государства. 
Formulation of the problem. The international and national security threats have increased over the last decade due to the likelihood of the emergence of new nuclear countries, the growing undetermined impact of the globalization processes on the development of international relations, especially because of fierce competition for the redistribution of spheres of influence to the global economy, which is also being felt in the energy sector, as well as, the use of forceful methods in the realization of the national interests. In most countries there is a steady increase in the cost of developing advanced weapons systems. As a result, the question of the existence of Ukraine as an integrated and sovereign state can be put on the agenda if the accumulated potential of threats to the national security is not realized without the use of appropriate mechanisms of development and implementation of the state policy aimed at protecting the interests of the state [1, p. 11].

In my opinion, the main mechanism for implementing such a policy is public administration in the field of national security. Public administration, as a way of being a social organization, is an integral part of it. The public administration that ensures the functioning and development of the society, as a whole, is carried out within the political system and includes the political aspect, as well as related forms of the state. In the modern scientific research the public administration is regarded as a phenomenon and a process that is carried out mainly within the executive branch of the government [2]. At the same time, in my opinion, the public administration is not limited to the ac- tivity of the executive authorities due to interaction with other state-governmental structures, legislative and judicial branches of the government that significantly influences the economic and socio-political environment.

Analysis of the recent research and publications. In the field of national security the public administration is characterized by features that are significantly differentiated, for example, by specific means of governance, by a certain course of action, and by issues of the influence on certain processes. The work of H. Sytnyk [3], S. Kruk [4], O. Evsyukova [5], T. Stukalina [6], S. Larina [7], A. Pomaz-Ponomarenko [8], M. Orl [9] and others is devoted to the study of the processes of the public administration in the field of the national security of Ukraine. It is worth noting that the process of forming a categorical-conceptual apparatus of the national security becomes virtually impossible without the scientific perception of the basics of its legislative consolidation, the basic legislative norms that regulate the social relations in the process of ensuring the protection of important interests of the individual and the citizen, the society and the state from internal and external threats. So, in this context, it should be understood what security is as a whole.

The purpose of the article is to outline the categorical and state-administrative aspects of the national security formation.

\section{Presentation of the main material.} The scientists are exploring the concept of "security" as a complex social phenomenon, using different approaches and aspects to its interpretation, which, 
in turn, leads to the lack of a single definition and vision of the content of the concepts of "security" and "national security". It should be noted that the concept of "security" is much broader than the concept of "national security"; it is generic for the concept of "national security". In the modern scientific literature security is interpreted differently, for example [10]:

- from the point of view of psychological knowledge it is the need to protect the vital interests of the people;

- from the point of view of philosophical and sociological knowledge it is the state and tendencies of the development of the state structures, institutions and moods of the population, rational balance of the freedom and means for its protection;

- from the point of view of legal knowledge it is a system of legal guarantees that provides a full guarantee of the human rights and freedoms defined by the laws for the protection of individuals, society and others.

The growing interest in the study of the essence of the concept of "security" in the context of its world-philosophical understanding depends on many factors. These include, in particular, the complexity and inconsistency of the current processes of transformation of the geo-political and geo-economic fields, the awareness of the need to solve global security problems and fundamental socio-political and socio-economic changes that have recently been traced in many countries of the world and have a decisive impact on the international and national security.

As a rule, when studying the essence of the term "security" the scientists focus on its three dimensions:
- conceptual (ontological and epistemological bases of security);

- practical (security is considered in the context of reflecting the specific needs of the individual, society, state and international community);

- value (security philosophy, security culture, etc.).

In turn, many scientists combine the concept of "security" with the concept of "danger". This is mainly due to the instinct for self-preservation in the evolution of the wildlife. That is, the existence of any living creature depends on how it can identify and evaluate the factors (including environmental factors) that threaten its physical existence [11].

Thus, it should be noted that danger and security is a dialectical interaction that is dynamically integrated and characterizes the living conditions of the objects in nature. It is worth noting that there is no security without danger and vice versa. What is more, what is dangerous for one object, it is safe for another, and what is safe for one, it is dangerous for another. Let us take a closer look at some aspects of security, see table.

So, as the table shows, security is one of the most important human needs, along with the need for food, clothing, shelter, and more. This means that the need for security is a basic prerequisite for the emergence of people into the world, and its ensuring is the basis for the progressive development of the society. At the present stage, the domestic and foreign scientists view security as a state of protection against certain threats and dangers. Therefore, the Interpretive Dictionary of the Ukrainian language defines security as a 
Characteristics of security aspects

\begin{tabular}{|c|l|l|}
\hline № & \multicolumn{1}{|c|}{ Security aspect } & \multicolumn{1}{c|}{ Characteristics of security aspects } \\
\hline 1 & Ontological & $\begin{array}{l}\text { Security exists in various forms (nature, human being, } \\
\text { social and spiritual aspects of being an individual) in } \\
\text { which the overall structure of its existence and dangers } \\
\text { are minimized. This objective reality protects everything } \\
\text { living, including the phenomena, processes and laws } \\
\text { that operate in the world }\end{array}$ \\
\hline 2 & Epistemological & $\begin{array}{l}\text { Security aspects are directly related to the characteris- } \\
\text { tics of its knowledge. In the course of the historical de- } \\
\text { velopment sensory experience and rational knowledge } \\
\text { of the basics of security are assimilated. The accumu- } \\
\text { lated knowledge is transformed into practical experi- } \\
\text { ence and reliable information }\end{array}$ \\
\hline 3 & Axiological & $\begin{array}{l}\text { The axiological aspect is that security has many univer- } \\
\text { sal values, such as good, truth and beauty, although its } \\
\text { content and meanings are different in different periods. } \\
\text { Security creates the best conditions for maintaining a } \\
\text { harmonious nature and sustainable development of the } \\
\text { society. Information about security gives a person the } \\
\text { freedom to make choices and shows his worth }\end{array}$ \\
\hline
\end{tabular}

state where nothing threatens anyone [12].

The term "security" in V. Dal's explanatory dictionary is defined as "lack of security; preservation, reliability..." [13, p. 67], but in our view such a simplified view of the concept of "security" is insufficient, especially when interpreted in a purely linguistic context, since the absence of danger means that a person can achieve such an ideal situation when there are no difficulties and threats to the society. However, in real life threats have always existed, exist and will exist, moreover, they have different structures and scales to address the challenges of the human civilization.

It is worth mentioning that the research of V. Lypkan, who made a certain typology of the concept of "security", based on the analysis of normative legal acts, relevant doctrines and concepts, as well as encyclopedic and reference literature, concluded that there is four approaches to interpreting the concept of "security" [14, p. 363-363]:

- statistical (security as a state of safety);

- apophatic (security as the absence of threats and dangers);

- active (security as a system of measures aimed at creating certain safe living conditions);

- passive (security as compliance with certain parameters and norms, on ensuring of which it depends directly).

I believe that such a versatile interpretation makes it possible to view security as a specific feature of dynamic social change and as a complex criterion for assessing its quality that characterizes the state of development of the modern governmental processes. V. Mohylevsky also emphasizes his attention considering security as "an indicator of the quality of any modern system as a whole" [15, p. 225]. 
According to A. Wolffers security objectively means no threats, and subjectively, no fear, that is, the feeling that no harm will be done to the public values [16]. In my opinion, considering security as a certain state of protection of the people from threats and dangers is a somewhat simplistic, utilitarian approach whereby certain values and interests are acquired, and if such values (interests) are threatened, then the danger is fixed.

In the process of developing ideas of the discursive democracy, security was seen as a value, a certain public interest, a good. However, this approach does not take into account that the concept of "security" can be interpreted more broadly as a category of philosophical and, therefore, a category of theory of the public policy and public administration. In particular, H. Sytnyk draws attention to this stating that the concept of "security" is a philosophical category and its essence has not been fully explored in scientific terms, especially when it comes to national security. The evidence of this is the constant debate around different approaches to defining the concept and ensuring the national security [17, p. 35].

It should be noted that when the concept of "national security" was included in the political lexicon in the West, it was used, first of all, as a synonym for the defense capability of the state and, until the mid-1980s, in the East and West of Europe this concept was understood as military and political security. The situation changed somewhat in the early 1990s when they began to consider the "national security" and the problems of its security from different sides and aspects, analyzing them in theoretical studies, philosophical, sociological and political literature.

To date, both in the East and the West of Europe have developed a certain understanding of the main categories used in developing ways of overcoming the ensurance of the national security issues. In our view, this contributes to the gradual formation of a sufficiently structured, relatively clear conceptual framework for the main legislative documents for the implementation of the national security. However, until now, researchers have not come to an agreement on what can be understood by the very concept of "national security" - a state or a category that characterizes that state [18, p. 104].

It should be noted that studying the categorical and state-administrative aspects of the formation of the national security institute, in particular, its concept and content, it is investigated that the term "national security" was first defined after the Second World War. In view of this, it should be noted that the idea of national security is formulated at the legislative level in the United States - in the Law "On National Security" (1947). Although interesting for science is the fact that the term "national security" was first introduced into the US state-legal lexicon by the President T. Roosevelt in 1904 and practically until 1947 was used in the sense of defense, was considered as a process of certain integration of the state's foreign, domestic and military policies.

Conclusions. Summarizing the above, I would like to point out that the theoretical definition of the scientific concept of "national security" is a priority, since it should reveal the essence of 
this state, social and legal phenomenon, find its content and emphasize the most important aspects, dependencies and elements. The analysis of the approaches to defining the scientific concept of "national security" shows that the classical vision of this social phenomenon is limited for some reason because:

- the perception of the national security arises mainly from the military interpretation of this category, which leads to a considerable limitation of its content;

- national security is associated with the notion of a state that guarantees its ensurance;

- the internal components of the national security are ignored;

- relativity and subjectivity of the perception of the nature of the concept of "national security", etc.

\section{REFERENCES}

1. Sytnyk H. P. (2012). Derzhavne upravlinnia u sferi natsionalnoi bezpeky (kontseptualni ta orhanizatsiino-pravovi zasady) [Public Administration in the field of national security (conceptual and organizational legal bases)]. Kyiv: NADU [in Ukrainian].

2. Kaliaiev A. (2018). Teoretychni pidkhody shchodo transformatsii suchasnykh modelei derzhavnoho upravlinnia u sferi bezpeky ta oborony [Theoretical approaches to the transformation of modern models of public administration in the field of security and defense]. Efektyonist derzhavnoho upravlinnia - Efficiency of public administration, 1 (54), 1, 13-19 [in Ukrainian].

3. Sytnyk H. P. (2017). Instytutsiinotsyvilizatsiinoi paradyhma, yak osnova metodolohii derzhavnoho upravlinnia u sferi natsionalnoi bezpeky [Institutional-civilizational paradigm as the basis of the methodology of public administration in the field of national security]. Naukovyi chasopys Akademii natsionalnoi bezpeky - Scientific journal of the National Security Academy, 1-2, 10-23 [in Ukrainian].

4. Kruk S. I. (2018). Orhanizatsiinyi mekhanizm derzhavnoho upravlinnia u sferi zabezpechennia natsionalnoi bezpeky Ukrainy [Organizational Mechanism of Public Administration in the Field of National Security of Ukraine]. Derzhava ta rehiony. Seriia: Derzhavne upravlinnia - State and Regions. Series: State Administration, 3(63), 105-108 [in Ukrainian].

5. Evsiukov O. P. (2017). Naukovoteoretychni vyznachennia sutnosti ta zmistu bezpeky derzhavy [Scientific theoretical definitions of the essence and content of the state security]. Visnyk Natsionalnoho universytetu tsyvilnoho zakhystu Ukrainy. Seriia: Derzhavne upravlinnia - Bulletin of the National University of Civil Defense of Ukraine. Series: Public Administration, 2(7), 22-28 [in Ukrainian].

6. Stukalin T. A. (2016). Systema derzhavnoho upravlinnia u sferi oborony derzhavy ta osnovni napriamy yii rozvytku v konteksti reformuvannia sektora bezpeky i oborony [The system of public administration in the field of state defense and the main directions of its development in the context of security and defense sector reform]. Teoriia ta praktyka derzhavnoho upravlinnia Theory and Practice of Public Administration, 2(53), 213-220 [in Ukrainian].

7. Larin S. V. (2017). Aktyvizatsiia vzaiemodii derzhavy i suspilstva shchodo zakhystu natsionalnykh tsinnostei u sferi natsionalnoi bezpeky [Activation of interaction between the state and society on the protection of national values in the field of national 
security]. Derzhava ta rehiony. Seriia: Derzhavne upravlinnia - State and Regions. Series: Public administration, 3, 16-20 [in Ukrainian].

8. Pomaza-Ponomarenko A. L. (2015). Napriamy ta metodolohiia formuvannia natsionalnoi bezpeky $\mathrm{v}$ rehionalnykh umovakh [Directions and methodology of national security formation in regional conditions]. Publichne upravlinnia ta mytne administruvannia Public Administration and Customs Administration, 2(13), 194-199 [in Ukrainian].

9. Orel M. H. (2018). Politychna bezpeka yak skladova natsionalnoi bezpeky: teoretychnyi aspekt [Political Security as a Component of National Security: A Theoretical Aspect]. Naukovyi chasopys Akademii natsionalnoi bezpeky Scientific Journal of the National Security Academy, 1, 22-34 [in Ukrainian].

10. Skulysh S. D., Bohdanovych V. Yu., Svyda I. Yu. (2012). Teoretykometodolohichni osnooy zabezpechennia natsionalnoi bezpeky Ukrainy. T. 1: Teoretychni osnovy, metody y tekhnolohii zabezpechennia natsionalnoi bezpeky Ukrainy [Theoretical and methodological foundations of national security of Ukraine. Vol. 1: Theoretical bases, methods and technologies of national security of Ukraine]. S. D. Skulysha (Eds.). Kyiv: Nauk.-vyd. viddil NA SB Ukrainy [in Ukrainian].

11. Sytnyk H. P. (2011). Derzhavne upravlinnia u sferi natsionalnoi bezpeky (kontseptualni ta orhanizatsiino-pravovi zasady) [Public Administration in National Security (Conceptual and Organizational-Legal Framework)]. Kyiv: NADU [in Ukrainian].

12. Slovnyk ukrainskoi movy [Dictionary of the Ukrainian language]. (1970). (Vols. 1). I. K. Bilodida (Eds.). Kyiv: Naukova dumka [in Ukrainian].

13. Dal V. I. (1978). Tolkovyy slovar zhivogo velikorusskogo yazyka [Explanatory
Dictionary of the Living Great Russian Language]. (Vols. 1). Moscow: Russkiy yazyk [in Russian].

14. Lipkan V. A. (2009). Teoriia natsionalnoi bezpeky [Theory of National Social Security]. Kyiv: KNT [in Ukrainian].

15. Mogilevskiy V. D. (2001). Vvedenie $\mathrm{v}$ teoriyu upravleniya bezopasnostyu sistem [Introduction to the theory of security management systems]. Problemy bezopasnosti pri chrezoychaynykh situatsiyakh - Safety problems in emergency situations, 4, 215-235 [in Russian].

16. Wolfers A. (1962). Discord and Collaboration: Essays on International Politics. Baltimore: Johns Hopkins University Press [in English].

17. Sytnyk H. P. (2004). Derzhavne upravlinnia u sferi zabezpechennia natsionalnoi bezpeky Ukrainy: teoriia i praktyka [State Administration in the Sphere of Protection of the National Security of Ukraine: Theory and Practice]. Doctor's thesis. Kyiv [in Ukrainian].

18. Petrovskiy V. F. (1980). Doktrina "natsionalnoy bezopasnosti” v globalnoy strategii SShA [The Doctrine of "National Security" in the US Global Strategy]. Moscow: Mezhdunar. Otnosheniya [in Russian].

\section{СПИСОК ВИКОРИСТАНИХ ДЖЕРЕЛ}

1. Ситник Г. П. Державне управління у сфері національної безпеки (концептуальні та організаційно-правові засади): підручник К.: НАДУ, 2012. $544 \mathrm{c}$.

2. Каляєе А. Теоретичні підходи щодо трансформації сучасних моделей державного управління у сфері безпеки та оборони // Ефективність державного управління. 2018. Вип. 1 (54). Ч. 1.

3. Ситник Г. П. Інституційно-цивілізаційної парадигма, як основа методо- 
логії державного управління у сфері національної безпеки / Г. П. Ситник // Наук. часопис Академії національної безпеки. 2017. № 1-2. $162 \mathrm{c}$.

4. Крук C. I. Організаційний механізм державного управління у сфері забезпечення національної безпеки України // Держава та регіони. Серія: Державне управління, 2018. № 3 (63).

5. Евсюков О. П. Науково-теоретичні визначення сутності та змісту безпеки держави // Вісн. Національного ун-ту цивільного захисту України. Серія: Державне управління. 2017. Вип. 2 (7).

6. Стукалін Т. А. Система державного управління у сфері оборони держави та основні напрями iㅣ розвитку в контексті реформування сектора безпеки і оборони // Теорія та практика державного управління 2(53)/2016, $221 \mathrm{c.}$

7. Ларін С. В. Активізація взаємодії держави і суспільства щодо захисту національних цінностей у сфері національної безпеки / С. В. Ларін // Держава та регіони. Серія: Державне управління: наук.-вироб. журн. Вип. 3. Запоріжжя: КПУ. 2017.

8. Помаза-Пономаренко А. Л. Напрями та методологія формування національної безпеки в регіональних умовах // Публічне управління та митне адміністрування, № 2 (13), 2015.

9. Орел М. Г. Політична безпека як складова національної безпеки: теоретичний аспект // Наук. часопис Академії національної безпеки. 2018. № 1.95 c.

10. Скулиш С. Д. Теоретико-методологічні основи забезпечення націо- нальної безпеки України: моногр.: у 7 т. Т. 1: Теоретичні основи, методи й технології забезпечення національної безпеки України / В. Ю. Богданович, І. Ю. Свида, Є. Д. Скулиш ; за заг. ред. С. Д. Скулиша. К: Наук.вид. відділ НА СБ України, 2012. $548 \mathrm{c}$.

11. Ситник Г. П. Державне управління у сфері національної безпеки (концептуальні та організаційно-правові засади): підручник. К.: НАДУ, 2011. $730 \mathrm{c}$.

12. Словник української мови [Текст]: в 11 т. Т. 1 / за ред. І. К. Білодіда, АН УРСР. Інститут мовознавства. К.: Наук. думка, 1970.

13. Даль В. И. Толковый словарь живого великорусского языка. Т. 1-4. Москва: Русский язык, 1978. Т. 1: А-3. 1978.

14. Ліпкан В. А. Теорія національної безпеки: підручник / В. А. Ліпкан. К.: КНТ, 2009. 576 с.

15. Могилевский В. Д. Введение в теорию управления безопасностью систем / В. Д. Могилевский // Проблемы безопасности при чрезвычайных ситуациях [Текст]. 2001. № 4 .

16. Wolfers A. Diskort and Collaboration, Essays on International Politics ext] / A. Wolfers. Baltimore: Johns Hopkins University Press, 1962. P. 150.

17. Ситник Г. П. Державне управління у сфері забезпечення національної безпеки України: теорія і практика: дис. д-ра наук з держ. управління / Г. П. Ситник. К., 2004. 417 с.

18. Петровский В. Ф. Доктрина “национальной безопасности” в глобальной стратегии США. Москва: Междунар. отношения, 1980. 